\title{
Perceptions of Unfairness in the Management of Bullying Complaints: Exploring the Consequences
}

\author{
Moira F Jenkins ${ }^{1}$, Helen Winefield ${ }^{1} \&$ Aspa Sarris ${ }^{1}$ \\ ${ }^{1}$ School of Psychology, University of Adelaide, Adelaide, Australia \\ Correspondence: Dr. Moira F Jenkins, Adjunct Lecturer, School of Psychology, University of Adelaide, North \\ Terrace, Adelaide 5005, South Australia, Australia. E-mail: moira.jenkins@aboto.com.au
}

Received: May 18, 2013

Accepted: June 27, 2013

Online Published: July 2, 2013

doi:10.5430/ijba.v4n4p16

URL: http://dx.doi.org/10.5430/ijba.v4n4p16

\begin{abstract}
This exploratory study aimed to examine why some bullied workers submitted compensable injury claims for psychological injury after they had made a workplace bullying grievance, and others did not. This study was carried out using a mixed methodology. Forty-four participants who had complained about bullying at work completed a survey about their experiences, and 31 were interviewed. A thematic analysis of the interview data was undertaken. Those participants who submitted workers' compensation claims were found to be significantly more depressed than those who did not submit workers' compensation claims, although no significant differences were found between the anxiety and stress scores of all participants. Results also indicated that participants who submitted a workers' compensation claim perceived less organisational justice in the way their complaint of bullying was managed than those participants who did not submit a claim. These results were endorsed by the qualitative aspects of the study where themes of frustration and unfairness were closely linked with the decision to submit a workers' compensation claim. This is one of the few studies that have examined the effect of an organisation's response to workplace bullying allegations on an employee's decision to claim workers' compensation for psychological injury.
\end{abstract}

Keywords: workplace bullying, organizational justice, stress leave, workers compensation, psychological injury

\section{Introduction}

The management of justice and perceptions of fairness in the workplace is becoming recognised as an important issue for administrators. Lack of justice, or perceptions of unfair processes and polices can lead to workers retaliating in a number of ways, including making workers compensation claims and suing employers for practices considered to be unfair (Winefield, Saebel \& Winefield, 2010). In Australia, workers who are injured at work are able to make a claim for workers' compensation insurance for the leave required to recover from their workplace injury and for rehabilitation and treatment expenses incurred as a result of the injury. This leave is commonly referred to as 'stress leave' in relation to psychological injuries. Workers may apply for compensable leave if the workplace was the substantial cause of that injury. As well as physical injuries, employees with diagnosed psychological injuries or mental disorders that have been caused by high levels of workplace stress such as workplace bullying may require time off work as well as rehabilitation; both which are compensable (if the substantive cause of their mental disorder was the workplace) though their employers workers' compensation insurance. While mental disorders only make up $6 \%$ of all workers' compensation claims, this category of claimants make up the longest time lost at work, averaging ten weeks of lost work days compared to the median of four weeks of time (Australian Occupational Health and Safety Compensation Council, 2007). This makes stress leave claims very expensive in terms of both lost time and financial cost compared to physical injury claims. The consequences of perceptions of unfairness in the administration of workplace polices and complaint process following workplace bullying and harassment allegations have not previously been explored. It is hypothesised that perceptions of unfairness will influence a complainants decision to lodge workers compensation claims for psychological injury after they have made a complaint of workplace bullying.

\section{Workplace Bullying}

Workplace bullying has been established as a major psychological hazard in the workplace, with over three decades of research establishing that exposure to bullying has a detrimental effect on the health and wellbeing of targets and witnesses (Hogh, Mikkelsen \& Hansen, 2011; Vartia, 2001). Although there are numerous definitions of workplace bullying, a comprehensive definition that is widely used is:

Harassing, offending or socially excluding someone or negatively affecting someone's work. In order for the label of bullying or mobbing to be applied to a particular activity the bullying behaviour has to occur 
repeatedly and regularly (e.g., weekly) and over a period of time (e.g., about six months). Bullying is an escalating process in the course of which the person confronted ends up in an inferior position and becomes the target of systematic negative social acts. A conflict cannot be called bullying if the incident is an isolated event or if two parties of approximately equal strength are in conflict (Hoel, Zapf \& Cooper, 2011, p. 22).

This definition highlights some important features of bullying that differentiate it from workplace conflict and other forms of workplace incivility. Bullying involves repeated acts of offensive or threatening behaviours. There is a power differential between target and perpetrator, and the escalating nature of workplace bullying means that if not addressed, over time the behaviour gets worse. Because of the interaction of these specific features, workplace bullying often results in the target sustaining an injury. This is highlighted in a number of studies that have have shown that workplace bullying can contribute to both mental and physical disorders (Cooper, 2002; Einarsen \& Mikkelsen, 2003; Hoel, Vartia, 2001; Zapf, Knorz \& Kulla, 1996; Zapf \&; Niedl, 1996) along a continuum from increased risk of cardiovascular disease and depression (Kivimaki et al., 2003) to Post Traumatic Stress Disorder (Matthiesen \& Einarsen, 2002, 2004; Tehrani, 2004). Workplace bullying has been found to be associated with an increase in workplace absenteeism, with higher than normal levels of sick leave being one of the first signs of the impact of workplace bullying (Kivimaki, Elovainio \& Vahtera, 2000). While workers who are injured as a result of workplace bullying and harassment are able to make a workers' compensation claim, few studies have examined the reasons why some employees lodge claims and others do not. Further, to date, the perception of an organisation's response to an employee's complaint of workplace bullying on an employee's decision to make a workers' compensation claim, has not been examined.

\section{Justice}

\subsection{Perceptions of Organisation Justice}

Organisational justice has been referred to as the 'just and fair manner in which organisations treat their employees' (Greenberg, 1990). An examination of the organisational justice literature indicates that the terms 'justice' and 'fairness' are often used interchangeably (Miller, 2001), although fairness is more often used to explain justice in a generic sense. For example, the common expression 'that's not fair' is often use to describe a broad sense of injustice, while 'justice' describes specific aspects of fairness such as distributive, procedural and interpersonal justice (Cohen-Charash \& Spector, 2001; Colquitt, 2001; Colquitt, Conlon, Wesson, Porter \& Ng, 2001; Greenberg, 1990). When relating these concepts to a workplace bullying complaint, distributive justice refers to the fairness of the specific decisions that are made in relation to the outcome of the complaint. Procedural justice refers to fairness in the way that the decision was made, for example, the transparency of the decision-making process, the ability of all parties to tell their side of the story, and the ability of both parties to have equal representation. Interactional justice refers to perceptions of respect and sensitivity and is viewed in terms of the interactions between the decision makers and the complainant / respondent.

\subsection{Violation of Perceptions of Justice}

The negative reaction of employees when their perception of justice is violated can be significant (Bias \& Tripp, 1996; Cohen-Charash \& Mueller, 2007; Cohen-Charash \& Spector, 2001). Bias and Tripp (1996) found that individuals contemplate revenge and respond aggressively when organisational trust is violated and when an employee develops a negative evaluation of fairness within the organisation. Likewise, a number of other studies have supported the view that employees' evaluations of fairness within the organisation influence their attitudes, organisational citizenship behaviour (Moorman, 1991; Niehoff \& Moorman, 1993), level of sick leave taken and general health (Elovainio, Kivimaki \& Vahtera, 2002), including psychological distress (Surinen, Kivmaki, Elovainio \& Virtanen, 2002) and depression (Ylipaavalniemi et al., 2005), as well as their decision to lodge workers' compensation claims following a workplace injury (Dollard, Winefield, H. \& Winefield, A; 1999; Roberts \& Markel, 2001; Winefield, Saebel \& Winefield, 2010). Winefield et al. (2010) found that negative perceptions of organisational justice, in particular, the perceived unfairness of workplace policies and procedures governing workplace decision making, were predictors of claiming for psychological injury. Workers who felt helpless, who believed decisions were made unfairly and who believed they were treated without respect were more likely to make a claim for psychological injury than those workers who believed that they had been treated fairly by the organisation (Winefield et al., 2010). In a similar study, Haines, Williams and Carson (2004) found that individuals who lodged compensation claims reported significantly less organisational support than those who reported psychological injury due to workplace stress, but had not claimed workers' compensation. Other studies have found that the way the organisation responds to stressful workplace incidents or injuries significantly influences the decision of the injured worker to lodge a workers' compensation claim (Dollard et al., 1999; Roberts \& Markel, 2001; Roberts \& Young, 1997). Jenkins (2013) highlights the importance of the adherence to the rules of natural justice throughout any intervention into allegations of bullying or harassment. 
However, she goes further and stresses the importance of 'post intervention processes' that allow parties in dispute to address ongoing relationship issues and areas of conflict within a 'restorative justice' framework. This follows Nesbit, Nabatchi and Bingham (2012) who found that high levels of interpersonal justice when workplace disputes were mediated, was an important element in the resolution of the dispute. Specifically they found that when both parties listened to each other, and supervisors acknowledged the employee's perception of the dispute, full resolution was more likely. They concluded that not only were disputants perceptions of justice important, but the extent to which the disputants perceptions of justice, matched the actual behaviour of the other party was also important in resolving the conflict between them (Nesbit et al, 2012). More recent studies have examined more global perceptions of justice, and concluded that bullied employees global perceptions of a 'just world' have a significant influence on their intention to leave their organisation following workplace bullying (Öcel and Ayden, 2012).

It follows from these studies that for most employees, a workplace injury may be only one factor in their decision to claim workers' compensation, and justice perceptions are also important in determining the way employees behave following workplace bullying, or a workplace dispute. The way that an injury (or a potential injury) is dealt with in the workplace in terms of perceptions of justice or fairness in addressing the cause, may be a very important factor.

\section{Organisational Response to Injury}

A number of studies have found that an organisation's positive response to an employee's injury is a critical for successful rehabilitation and return to work (Dollard et al., 1999; Haines, Williams \& Carson, 2004; Roberts \& Markel, 2001). There is also some evidence that employees will retaliate against employers or managers whom they perceive as behaving in an unfair manner towards them (Aquino, Bias \& Tripp, 2006; Skarlicki \& Folger, 1997). Lodging a workers' compensation claim may be seen by an employee as revenge or retaliation for unfair treatment because of the costs associated with the claim for the employer. Indeed, Rosenman and colleagues (2000) found that only $25 \%$ of workers who had been diagnosed with a work-related musculoskeletal disorder actually filed a workers' compensation claim, despite injuring themselves at work. While severity of illness was the best predictor of filing a claim, lack of job satisfaction, poor perceptions of procedural justice, feeling unrespected at work, and perceptions that rewards were not distributed in accordance with job performance were all associated with an increased likelihood of filing a workers' compensation claim (Rosenman et al., 2000). These findings support the proposition that workers' perceptions of fairness will have some bearing on the outcome following a workplace injury resulting from workplace bullying. Indeed, in a review of the justice literature, Miller (2001) highlights the importance of apology following an offence or wrongdoing. He argues that perceptions of continuing rule violation through lack of apology or remorse serve to provoke punishment from targets. This is because by not expressing remorse, the validity or severity of the offence is challenged. Miller (2001) further asserts that offences conducted in a public arena, that threaten a targets 'face' and 'status' are more likely to result in retaliatory behaviour, especially if the severity and impact of the offence is not publicly acknowledged.

These studies suggest that the way that an organisation manages a complaint of workplace bullying can have significant consequences. Complaints of workplace bullying that are managed unfairly may have negative consequences for both employees and organisations. Poor perceptions of justice, lack of apology or validation of the target's suffering by an organisation may result in retaliatory behaviour and influence a bullied target's decision to lodge a workers' compensation claim.

\section{Aims of This Study}

There have been very few studies examining the impact of organisational justice perceptions following complaints of workplace bullying. This exploratory study aims to fill that gap and examine whether an employee's perception of justice following a workplace bullying complaint affects their decision to lodge a workers' compensation stress claim for psychological injury. Given that workers who are injured as a result of bullying are able to make a claim for workers compensation for the medical expenses and leave required to recover from their injury, if follows that participants in this study who claimed workers compensation following workplace bullying will report greater depression, anxiety and stress than those who did not claim workers compensation. Therefore, the primary questions are: Why did some participants make a decision to claim workers' compensation following their allegation of bullying? Was this decision related to the severity of their injury, or did the way the organisation respond to their complaint of bullying influence their decision?

Hypothesis 1: Participants who submitted a workers' compensation claim are expected to report more severe symptoms of depression, anxiety and stress as a result of workplace bullying than those participants who did not submit a workers' compensation claim.

Hypothesis 2: Participants who submitted a workers' compensation claim are expected to have a more negative evaluation of organisational justice than those participants who did not submit a workers' compensation claim. 


\section{Methodology}

This exploratory study adopted a mixed-method design, which included a qualitative/interview component, and a descriptive survey. To achieve the aims of this study, participants were recruited following a media release and invitation via radio and newspaper interviews to participate in a study about workplace bullying. Participants were self-selected and contacted the researcher if they wanted to participate in the study. Participants were eligible to participate if they believed they had been bullied at work over the previous two years, and had made a complaint about their bullying.

Forty-four participants were recruited for the study (17 males and 27 females). The age of participants ranged from 22 years of age to 78 years of age, with the median age being 50 years of age. Thirty-three participants described themselves as workers. Eight participants said they were working in middle management and three described themselves as working in a senior management role. Twenty-one participants were employed by the Public Service. Fifteen were employed in the private sector and seven were employed in either the not-for-profit or the community service sector. One participant was an independent contractor employed by a board.

Twenty-one participants were currently working full time and five were working part time. Twelve participants were not currently working, but were receiving workers' compensation, and four were on a return-to-work program. One participant described himself as unemployed and one as carrying out unpaid work.

Thirty-one of the participants were interviewed as part of the qualitative part of the study. Thirteen participants were not interviewed because they volunteered to participate in the study after the qualitative/interview part of the data collection had been completed. All 44 participants completed a survey (17 males and 27 females).

\subsection{Qualitative Interviews}

The semi-structured interview used in this study was based around an interview guide that was made up of a series of open-ended questions derived from the literature on workplace bullying. The guide was designed to engage the participant in talking about specific aspects of their experience. The interviewer was able to deviate from the guide if a participant raised an important issue or provided an unusual answer to a question. The interviewer followed up questions with probes such as 'can you tell me more about that' or 'there seems to be a discrepancy between what you said ... and ... can you tell me about that?' The interviews lasted around one hour to one and half hours in length and were audio recorded, and then transcribed. Names of the participants were changed during the transcription and identifying features of the organisation were removed from the transcripts or changed in order to preserve the anonymity of the participants.

\subsubsection{Analysis of Transcripts and Coding of Interview Data}

Transcripts were analysed using the thematic qualitative method of enquiry developed by Braun and Clarke (2006) who described six phases enquiry, as illustrated in Table 1.

Table 1. Phases of thematic analysis (Braun \& Clarke, 2006, p. 7)

\begin{tabular}{|c|c|c|}
\hline & Phase & Description of the process \\
\hline 1 & $\begin{array}{l}\text { Familiarising yourself } \\
\text { with your data }\end{array}$ & $\begin{array}{l}\text { Transcribing data (if necessary), reading and re-reading the data, } \\
\text { noting down initial ideas }\end{array}$ \\
\hline 2 & Generating initial codes & $\begin{array}{l}\text { Coding interesting features of the data in a systematic fashion } \\
\text { across the entire data set, collating the data relevant to each code }\end{array}$ \\
\hline 3 & Searching for themes & $\begin{array}{l}\text { Collating codes into potential themes, gathering all data relevant } \\
\text { to each potential theme }\end{array}$ \\
\hline 4 & Reviewing themes & $\begin{array}{l}\text { Checking to see if the themes work in relation to the coded } \\
\text { extracts (level 1) and the entire data set (level 2), generating a } \\
\text { thematic 'map' of the analysis }\end{array}$ \\
\hline 5 & $\begin{array}{l}\text { Defining and naming } \\
\text { themes }\end{array}$ & $\begin{array}{l}\text { Ongoing analysis to refine the specifics of each theme and the } \\
\text { overall story the analysis tells, generating clear definitions and } \\
\text { names for each theme }\end{array}$ \\
\hline 6 & Producing the report & $\begin{array}{l}\text { The final opportunity for analysis, selection of vivid, compelling } \\
\text { extract examples, final analysis of selected extracts, relating back } \\
\text { to the analysis of the research question and the literature, } \\
\text { producing a scholarly report of the analysis }\end{array}$ \\
\hline
\end{tabular}


Participants completed a short survey that gathered demographic information (age, sex and occupation) as well as measures of psychological health and perceptions of justice. The Depression Anxiety Stress Scales (DASS) (Lovibond \& Lovibond, 1995) were chosen to measure respondents' levels of anxiety, depression and stress. The DASS-21 is a 21-item self-report inventory that describes a number of symptoms assessing depression, anxiety and general non-specific arousal (stress). For example, stress - 'I was intolerant of anything that kept me from getting on with what I was doing'; anxiety-'I was worried about situations in which I might panic and make a fool of myself'; and depression - 'I found it difficult to work up the initiative to do things'. Respondents were asked to report the degree to which each symptom was experienced over the past week, on a four-point scale ranging from $0=$ did not apply to me at all, to $3=$ applied to me very much. As recommended in the DASS manual, the obtained scale scores were multiplied by two, so that they could be compared to the DASS normative data that is based on the 42-item questionnaire (Lovibond \& Lovibond, 1995).

Interpretation of the DASS is on the basis of percentile scores with scores of 0-78 classified as 'normal', 78-87 as 'mild', 87-95 as 'moderate', $95-98$ as severe and $98-100$ as 'extremely severe'(Lovibond \& Lovibond, 1995). In the current study, the reliability coefficients for the depression, anxiety and stress subscales of the DASS were all satisfactory with Cronbach's alphas of $.87, .91$ and .78 , respectively.

The Organisational Justice Scales (Colquitt, 2001) were utilised to measure the three dimensions of organisational justice. The first seven questions provide a measurement of procedural justice (e.g., 'to what extent do you think that the procedures and processes used to address your complaint were free from bias?'); four questions measure distributive justice (e.g., 'the outcome of my complaint is appropriate given the extent to which I was bullied or harassed'); and four items measure interpersonal justice (e.g., 'to what extent do you think the person who dealt with your complaint treated you in a polite manner?'). All items use a five point scale to measure the extent to each item reflects the way the respondent's complaint was managed from $1=$ never to $5=$ always. The reliability coefficients in the current study were high, with a reliability of .90 for procedural justice, .92 for interactional justice and .89 for distributive justice subscales.

\section{Results and Discussion}

Results from the survey questionnaires will be reported first, followed by the relevant themes identified in the interview data.

\subsection{Survey Results}

Sixty-three per cent of participants submitted a workers' compensation claim for stress-related leave as a result of a work-related psychological injury due to bullying (three participants did not specify whether they had submitted a claim or not).

As illustrated in Table 2, responses on the DASS indicated that most of the participants reported significant stress, anxiety and depression symptoms. While a small number of participants $(11.4 \%, \mathrm{n}=5)$ had a depression score on the DASS that fell within the normal to mild range of depression symptoms, the majority of participants $(88.6 \%, n=39)$ had depression scores on the DASS that ranged from moderate to extremely severe depressive symptoms. Fifty per cent of participants $(n=23)$ recorded depression scores in the extremely severe range. Similarly, a minority of participants $(18.2 \%, \mathrm{n}=8)$ reported anxiety in the normal to mild range, with the majority of participants reporting anxiety in the moderate to extremely severe range $(80.1 \%, \mathrm{n}=36)$. Over half the participants recorded anxiety scores in the extremely severe range. A minority of participants reported stress scores in the normal to mild range of stress $(11.3 \%, \mathrm{n}=5)$ and the majority reported stress scores within the moderate to extremely severe range of stress $(84.1 \%$, $n=37)$. Forty-three per cent of the sample $(n=19)$ recorded stress scores in the extremely severe range.

Table 2. Depression Anxiety and Stress Scale (DASS) scores

\begin{tabular}{l|c|c|c}
$\begin{array}{c}\text { DASS Severity } \\
\text { Ratings }\end{array}$ & Depression & Anxiety & Stress \\
\hline Normal range & & & \\
\hline Mild range & 9.1 & 9.1 & 4.5 \\
& $(\mathrm{n}=4)$ & $(\mathrm{n}=4)$ & $(\mathrm{n}=2)$ \\
\hline Moderate range & 2.3 & 9.1 & 6.8 \\
& $(\mathrm{n}=1)$ & $(\mathrm{n}=4)$ & $(\mathrm{n}=3)$ \\
\hline Severe range & 13.6 & 20.5 & 15.9 \\
& $(\mathrm{n}=6)$ & $(\mathrm{n}=9)$ & 6.8 \\
$(\mathrm{n}=7)$
\end{tabular}


The hypothesis that participants who submitted a workers' compensation claim would report more severe depression, anxiety and stress than those participants who had not submitted a workers' compensation claim was only partially supported. An independent samples $t$-test was conducted to compare the depression, anxiety and stress scores of those participants who had submitted a workers' compensation claim and those participants who had not submitted a claim. A significantly higher depression score was found in those participants who had submitted a claim $(M=33.0, S D=9.3)$ compared to those who had not submitted a claim $(M=22.9, S D=11.4) ; t(39)=3.0, p<.01$. However, no significant difference was found in anxiety scores of participants who had submitted a workers' compensation claim $(M=25.4$, $S D=12.8)$ and those who had not submitted a workers' compensation claim $(M=17.8, S D=14.5) ; t(39)=1.6, p>.05$. Similarly, no significant difference was found in the stress scores of participants who had lodged a workers' compensation claim $(M=31.6, S D=9.7)$ compared to those who had not submitted a workers' compensation claim $(M$ $=29.6, S D=7.9) ; t(38)=.62, p>.05$.

In order to test the hypothesis that workers who had submitted a workers' compensation claim would have a more negative evaluation of organisational justice, independent $t$-tests were was carried out with workers' compensation claim as the independent variable. Supporting the hypothesis that those participants who submitted a workers' compensation claim would report a significantly lower evaluation of organisational justice, perceived interpersonal justice was significantly lower in participants who had submitted a workers' compensation claim $(\mathrm{n}=26)(M=11.23$, $S D=5.34)$ compared to those who had not submitted a claim $(\mathrm{n}=13)(M=19.15, S D=.6 .30) ; t(20.86)=-3.88, p<.01$. Similarly, participants who submitted a workers' compensation claim $(M=10.60, S D=3.79)$ reported a lower perceived procedural justice than participants who had not submitted a claim $(M=20.16, S D=9.23) ; \underline{t}(12.69)=-.3 .46$, $p<.01$.) The hypothesis that participants who submitted a workers' compensation claim $(M=4.70, S D=1.78)$ would report a lower evaluation of distributive justice than those participants who had not submitted a claim $(M=8.23, S D=$ $5.30)$ was also supported $(t(13.32)=-2.30, p<.05)$.

\subsection{Results of Thematic Analysis}

The results of the thematic analysis suggested that the decision to apply for workers' compensation/stress leave was related to a combination of poor mental health attributed to the workplace bullying as well as a strong sense of injustice in the way the bullying allegations were managed within the workplace. The majority of participants who submitted a stress claim cited injustice as one of the main reasons for making a claim, believing that the organisation was not taking their bullying allegation seriously and they were not being treated fairly.

A small number of participants talked specifically about not wanting to make a stress claim because it was seen as a career-limiting move, and went against the perception of a 'good employee'. However, due to the impact of the bullying, and the way their complaint was being managed, they felt they had little option other than to make a workers' compensation claim. The following transcript illustrates this interaction between poor mental health and the unfair manner in which the bullying complaint is being managed, and how these variables interacted to contribute to the WorkCover claim:

First of all, I am 60 years of age. I have been in the workforce since I was 15, so effectively for 40 years. I have never had a WorkCover claim. Never wanted one. So I didn't want to take WorkCover as an option and I refused it initially, but things escalated with the problems I was having at work to a point where I had no option ... By this stage I had really fallen apart and so I went back to my doctor and said now I have got to take WorkCover, I've got to because I am just not well, and I am not getting paid, and HR [the alleged bully was the head of Human Resources] is making it worse, and I have to do something.

Another said:

That [lack of action] was very frustrating and I think the people who were the perpetrators knew that they were getting away with it ... So I think to me it just seemed as though they were going to continue with this behaviour until I had to put in a stress claim... and then I had to [put in a stress claim]. By the time they dealt with it, things had gotten so out of hand that I had actually left. I had actually gone on stress leave.

As illustrated by the quotations above, making a stress claim (also known as applying for WorkCover) was viewed as a last resort, as the first participant cited prided himself on having never made a claim in his 40 years of working life. Stress leave was only utilised as a last resort by both participants who felt they and 'had no option'. The quotations illustrate the themes of both illness ('I am just not well') and injustice ('and HR [the alleged bully was the head of HR] is making it worse, and I have to do something') that contributed to the claim being made. The second participant only lodged a stress claim because it appeared that the behaviour of the perpetrators' had not been stopped, and they saw that lodging a 'stress' claim was the only way in which the bullying behaviour would be 'dealt with' by the organisation. 
Most participants who lodged a stress claim reported that the process of managing their complaint of workplace bullying was unfair. The quotations cited below describe the relationship between this sense of unfairness and their decision to lodge a stress (WorkCover) claim:

I ended up going on WorkCover. I think I was very, very stressed by the initial bullying but the way they handled it made it worse and that is when I just went off [on stress leave] because I could see the way they were dealing with it. They weren't really interested in sorting out this intimidation that was going on.

Another said:

I went on WorkCover because all the complaints that I made at work weren't getting anywhere. Even when I made a formal complaint the investigations didn't work because they weren't investigations, they were just in my opinion covering their butt so that legally there wasn't any recall for them.

As illustrated by these quotations, the consequences of the initial bullying appeared to be exacerbated by the manner in which the organisation managed the complaints. The major themes expressed were a sense of frustration and unfairness in the way the organisations were managing or investigating the bullying allegations. It appears that this perception of mismanagement exacerbated the impact the bullying, and the focus of unfairness and anger moved away from the individual perpetrator to the organisation, who participants viewed as being responsible for the bullying through inaction and failure to address the behaviour properly. The majority of participants who submitted stress claims reported that having their claim accepted would be one way the organisation would be forced to take their complaint seriously.

\section{Conclusions and Recommendations}

The strong theme of injustice was highlighted by results of both the quantitative and qualitative parts of the study. While participants who lodged a stress claim following allegations of workplace bullying were found to have higher depression scores on the DASS than those who had not lodged workers' compensation claims, there were no significant differences found in the anxiety scores or stress scores of those who had lodged workers' compensation stress claims, compared to those who had not lodged claims. This was a surprising result and it may be that participants who were suffering high levels of depression could no longer function in the workplace due to their depressive symptoms, and subsequently left the workplace, applying for workers' compensation insurance. In contrast, symptoms of anxiety and stress are symptomatic of a highly stressful workplace, and results may reflect a situational or state anxiety as opposed to a clinical disorder per se. The symptoms of depression may reflect a more stable symptomatology and clinical depressive syndrome, more likely to be associated with compensable leave. Those participants who have taken leave may be less anxious because they are no longer in the workplace. It is interesting to note that while the anxiety difference is comparable to the depression difference, the difference in the anxiety scores between those participants who make compensation claims and those that didn't, failed to reach significance because the standard deviations in the anxiety scores were more dispersed. Given the limited sample size and the cross-sectional design of this exploratory study, in it is difficult to draw a valid conclusion from these results. However, these mixed findings do highlight the need for further research in the area of compensable mental health injuries and the difference between high levels of acute symptomatology such as situational anxiety and stress, compared with more clinical syndromes. Further, these results highlight the importance that perceptions of justice have on an employee's decision to make a works compensation claim for a psychological injury, and further research is needed in this area.

Applying for workers' compensation was seen by some participants as way of coping with the perceived unfair way in which their bullying allegation was being managed. Results indicated that participants who submitted a workers' compensation stress claim perceived less interpersonal justice, procedural justice and distributive justice than those participants who did not submit a claim. These results were endorsed by the qualitative aspects of the study where the theme of unfairness or injustice was closely linked with participants' decisions to lodge a stress claim following allegations of workplace bullying. These results support studies that indicate that relationships at work influence decisions to claim workers' compensation (Rosenman et al., 2000), and that an organisation's response to the workplace injury influences whether an employee will claim compensation (Dollard \& Knott, 2004; Roberts \& Markel, 2001). Results suggested that participants who felt that they could not trust the person who managed their complaint (interpersonal justice), who did not feel that the complaint-management process was fair (procedural justice) and who disagreed with the outcome of the complaint (distributive justice) were more likely to claim workers' compensation. Findings support those of Dollard et al. (1999) where workers who believed decisions were made unfairly and who believed they were treated without respect were more likely to make a claim for psychological injury than those workers who believed that they had been treated fairly by the organisation. In attempting to reduce the number of workers' compensation claims, managers and human resource practitioners need to emphasise the importance of 
fairness and ongoing support for potential claimants. Poor perceptions of justice in the way policies and procures are administered have the potential to result in retaliatory behaviour and influence a bullied target's decision to lodge a workers' compensation claim.

One of the criticisms of qualitative research is the perception that 'anything goes' (Braun \& Clarke, 2006) and this is often seen as a limitation by those researchers who are challenged by the emerging popularity of qualitative approaches in psychology. There are a number of guidelines that have helped legitimise qualitative research and allow qualitative research to develop and emerge as a valid methodology in its own right. The current study adhered to the guidelines suggested by and Braun and Clarke (2006) and Pope and Mays (2006) that help to ensure that the qualitative aspects of this study were methodologically rigorous.

However, there are some methodological limitations to this research. While Matthiesen and Einarsen (2001) advise against speaking about a general victim personality, it is possible that participants who volunteered to participate in research such as this were particularly affected by their bullying experience and represented a particular group of disaffected bully targets. This is a common problem in research on workplace conflicts and bullying, where it can be assumed that escalated cases are over-represented (Zapf \& Goss, 2001). The sample size was relatively small, with only 44 participants in the quantitative part of the study and 31 participants being interviewed. However, as acknowledged in previous research, given the exploratory nature of this study and the difficulty in recruiting participants who have lodged workers' compensation claims for psychological injury (Dollard et al., 1999), small numbers of participants are often characteristic of this area of research. Despite the small data set and methodological limitations, this study confirms many of the findings of more representative research as to why some workers lodge compensation claims for psychological injuries while others do not. In particular, this study suggests that perceptions of injustice may be an important reason why some bullied workers make a decision to lodge a claim. Few previous studies have specifically examined justice perceptions of bully targets in relation to complaining about workplace bullying. The results of this study highlight the importance of understanding the factors that might predispose a target of workplace bullying to submit a compensation claim. In particular, this study highlights that further research is needed, particularly in relation to the perception how of workplace bullying interventions (as opposed to the bullying itself) are administered and managed by the organisation.

\section{References}

Aquino, K., Bias, R., \& Tripp, T. (2006). Getting even or moving on? Power, procedural justice and types of offence as predictors of revenge, forgiveness, reconciliation and avoidance in organisations. Journal of Applied Psychology, 91(3), 653-668. http://dx.doi.org/10.1037/0021-9010.91.3.653

Australian Occupational Health and Safety Compensation Council. (2007). Compendium of workers' compensation statistics Australia 2004-05. Retrieved 15 May 2010, from http://www.safeworkaustralia.gov.au/NR/rdonlyres/A6032DB3-4F7B-4834-9D1E-C21E14605F04/0/PartEFeat ureMentalStress_WorkCompStats0405.pdf

Bias, R. J., \& Tripp, T. (1996). Beyond distrust: 'Getting even' and the need for revenge. In M. Kramer \& T. Tyler (Eds.), Trust in organisations (pp. 246-260). Thousand Oaks, CA: Sage Publications.

Braun, V., \& Clarke, V. (2006). Using thematic analysis in psychology. Qualitative Research in Psychology, 3(2), 77-101. http://dx.doi.org/10.1191/1478088706qp063oa

Caponecchia, C., \& Wyatt, A. (2009). Distinguishing between bullying, harassment and violence: A risk management approach. Journal of Occupational Health and Safety Australia and New Zealand, 25(6), 439-449.

Cohen-Charash, Y., \& Mueller, J. (2007). Does perceived unfairness exacerbate or mitigate interpersonal counterproductive workplace behaviours related to envy? Journal of Applied Psychology, 92(3), 666-680. http://dx.doi.org/10.1037/0021-9010.92.3.666

Cohen-Charash, Y., \& Spector, P. (2001). The role of justice in organisations: A meta-analysis. Organizational Behaviour and Human Decision Processes, 86(2), 278-231. http://dx.doi.org/10.1006/obhd.2001.2958

Colquitt, J. (2001). On the dimensionality of organisational justice: A construct validation of a measure. Journal of Applied Psychology, 86(1), 386-400. http://dx.doi.org/10.1037/0021-9010.86.3.386

Colquitt, J., Conlon, D., Wesson, M., Porter, C., \& Ng, K. Y. (2001). Justice at the millennium: A meta-analytic review of 25 years of organizational justice research. Journal of Applied Psychology, 86(3), 425-445. http://dx.doi.org/10.1037/0021-9010.86.3.425 
Dollard, M., \& Knott, V. (2004). Incorporating psychosocial issues into our conceptual models of OHS. Journal of Occupational Health and Safety, 20(4), 345-358.

Dollard, M., Winefield, H., \& Winefield, A. (1999). Predicting work stress compensation claims and return to work in welfare workers. Journal of Occupational Health Psychology, 4(3), 279-287. http://dx.doi.org/10.1037/1076-8998.4.3.279

Einarsen, S., Hoel, H., Zapf, D., \& Cooper, C. L. (Eds.) (2011). Bullying and harassment in the workplace: Developments in theory, research and practice. London, UK: Taylor and Frances.

Einarsen, S., \& Mikkelsen, E. (2003). Individual effects of exposure to bullying at work. In S. Einarsen, H. Hoel \& C. Cooper (Eds.), Bullying and emotional abuse in the workplace (pp. 127-141). London, UK: Routledge.

Elovainio, M., Kivimaki, M., \& Vahtera, J. (2002). Organizational justice: Evidence of a new psychosocial predictor of health. American Journal of Public Health, 92(1), 105-108. http://dx.doi.org/10.2105/AJPH.92.1.105

Greenberg, J. (1990). Organisational justice: Yesterday, today and tomorrow. Journal of Management, 16(2), 399-432. http://dx.doi.org/10.1177/014920639001600208

Haines, J., Williams, C. L., \& Carson, J. (2004). Workers' compensation for psychological injury: Personal and environmental correlates. Work, 22(3), 183-194.

Hoel, H., Zapf, D., \& Cooper, C. (2002). Workplace bullying and stress. In P. L. Perrewe \& D. C. Ganster (Eds.), Historical and current perspectives on stress and health (Vol. 2, pp. 293-333). UK: Emerald Group Publishing Limited. http://dx.doi.org/10.1016/S1479-3555(02)02008-5

Hoel, H., Zapf, D., \& Cooper, C. L. (2011). The concept of bullying and harassment at work: The European tradition. In S. Einarsen, H. Hoel, D. Zapf \& C. L. Cooper (Eds.), Bullying and harassment in the workplace: Developments in theory, research and practice (2nd ed., pp. 3-32). London, UK: Taylor \& Frances.

Hogh, A., Mikkelen, E. G., \& Hansen, A. M. (2011). Individual consequences of workplace bullying/mobbing. In S. Einarsen, H. Hoel, D. Zapf \& C. L. Cooper (Eds.), Bullying and harassment in the workplace: Developments in theory, research and practice (pp. 107-128). London, UK: Taylor and Frances.

Jenkins. (2013). Preventing and Managing Workplace Bullying and Harassment: A Risk Management Approach. Queensland, Australia; Australian Academic Press.

Kivmmaki, M., Elovainio, M., \& Vahtera, J. (2000). Workplace bullying and sickness absence in hospital staff. Occupational Environmental Medicine, 57(10), 656-660. http://dx.doi.org/10.1136/oem.57.10.656

Kivimaki, M., Virtanen, M., Vartia, M., Elovainio, M., Vahtera, J., \& Keltikangas-Jarvinen, L. (2003). Workplace bullying and the risk of cardiovascular disease and depression. Journal of Occupational and Environmental Medicine, 60(10), 779-783. http://dx.doi.org/10.1136/oem.60.10.779

Lovibond, S. H., \& Lovibond, P. F. (1995). Manual for the depression anxiety stress scales. Sydney, NSW: Psychology Foundation.

Matthiesen, S. B., \& Einarsen, S. (2004). Psychiatric distress and symptoms of PTSD among victims of bullying at work. British Journal of Guidance and Counselling, 32(3), 335-356. http://dx.doi.org/10.1080/03069880410001723558

Mikkelesen, E. G., \& Einarsen, S. (2001). Bullying in Danish work-life: Prevalence and health correlates. European Journal of Work and Organizational Psychology, 10(4), 393-413. http://dx.doi.org/10.1080/13594320143000816

Mikkelsen, E., \& Einarsen, S. (2002). Basic assumptions and symptoms of post-traumatic stress among victims of bullying at work. European Journal of Work and Organizational Psychology, 11(1), 87-111. http://dx.doi.org/10.1080/13594320143000861

Miller, D. T. (2001). Disrespect and the experience of injustice. Annual Review of Psychology, 52, 527-553. http://dx.doi.org/10.1146/annurev.psych.52.1.527

Moorman, R. (1991). Relationship between organizational justice and organizational citizenship behaviours: Do fairness perceptions influence employee citizenship? Journal of Applied Psychology, 76(6), 845-855. http://dx.doi.org/10.1037/0021-9010.76.6.845 
Nesbit, R; Nabatchi, T., \& Bingham, L. (2012). Employees, supervisors and workplace mediation: Experiences of justice and settlement. Review of Public Personnel Administration, 32(3), 260-287. http://dx.doi.org/10.1177/0734371X12436981

Niedl, K. (1996). Mobbing and well-being: Economic and personal development implications. European Journal of Work and Organizational Behaviour, 5(2), 165-184.

Niehoff, B. P., \& Moorman, R. H. (1993). Justice as a mediator of the relationship between methods of monitoring and organisational citizenship behaviours. Academy of Management Journal, 36(3), 527-556. http://dx.doi.org/10.2307/256591

Öcel, H., \& Aydın, O. (2012). Workplace bullying and turnover intention: The moderating role of belief in a just world. International Journal of Business and Social Science, 3(13), 248-258.

Pope, C., \& Mays, N. (Eds.). (2007). Qualitative research in health care. Oxford, UK: Blackwell Publishing.

Pope, C., Ziebland, S., \& Mays, N. (2006). Analysing qualitative data. In C. Pope \& N. Mays (Eds.), Qualitative research in health care (pp. 63-81). Oxford, UK: Blackwell Publishing. http://dx.doi.org/10.1002/9780470750841.ch7

Roberts, K., \& Markel, K. (2001). Claiming in the name of fairness: Organisational justice and the decision to file for workplace injury compensation. Journal of Occupational Health Psychology, 6(4), 332-347. http://dx.doi.org/10.1037/1076-8998.6.4.332

Roberts, K., \& Young, W. (1997). Procedural fairness, return to work and the decision to dispute in workers' compensation. Employee Responsibilities and Rights Journal, 10(1), 193-212. http://dx.doi.org/10.1023/A:1025602417477

Rosenman, K. D., Gardiner, J. C., Wang, J., Biddle, J., Hogan, A., Reilly, M. J., \& Welch, E. (2000). Why most workers with occupational repetitive trauma do not file for workers' compensation. Journal of Occupational and Environmental Medicine, 42(1), 25-34. http://dx.doi.org/10.1097/00043764-200001000-00008

Skarlicki, D., \& Folger, R. (1997). Retaliation in the workplace: The roles of distributive, procedural and interactional justice. Journal of Applied Psychology, 82(3), 434-443. http://dx.doi.org/10.1037/0021-9010.82.3.434

Surinen, R., Kivmaki, M., Elovainio, M., \& Virtanen, M. (2002). Organizational fairness and psychological distress in hospital physicians. Scandinavian Journal of Public Health, 30(3), 209-215. http://dx.doi.org/10.1080/14034940210133843

Tehrani, N. (2004). Bullying: A source of post-traumatic stress? British Journal of Guidance and Counselling, 32(3), 357-367. http://dx.doi.org/10.1080/03069880410001727567

Vartia, M. (2001). Consequences of workplace bullying with respect to the wellbeing of its targets and the observers of bullying. Scandinavian Journal of Work Environment and Health, 27(1), 63-69. http://dx.doi.org/10.5271/sjweh.588

Winefield, H., Saebel, J., \& Winefield, A. (2010). Employee perceptions of fairness as predictors of workers' compensation claims for psychological injury: An Australian case-control study. Stress and Health, 26(1), 3-12. http://dx.doi.org/10.1002/smi.1249

Ylipaavalniemi, J., Kivimaki, M., Elovainio, M., Virtanen, M., Keltikangas-Jarvinen, L., \& Vahtera, J. (2005). Psychosocial work characteristics and incidence of newly diagnosed depression: A prospective cohort study of three different models. Social Science and Medicine, 61(1), 111-122. http://dx.doi.org/10.1016/j.socscimed.2004.11.038

Zapf, D., Knorz, C., \& Kulla, M. (1996). On the relationship between mobbing factors and job content, social work environment and health outcomes. European Journal of Work and Organizational Psychology, 5(2), 215-238. http://dx.doi.org/10.1080/13594329608414856 